\title{
Effectiveness of Pentoxifylline Therapy for Management of Oral Submucous Fibrosis
}

\author{
Bajgai DP ${ }^{1}$, Agrawal $B^{1}$, Yadav $A^{2}$
}

\begin{abstract}
Introduction: Oral submucous fibrosis is a chronic oral disease characterized by progressive buildup of constricting collagen bands in the cheeks and adjacent structures of the mouth due to chewing of areca nut. This can severely restrict mouth opening and tongue movement causing pain and burning sensation in the mouth. Aims: This study evaluates the efficacy of pentoxifylline in the management of oral submucous fibrosis. Methods: A hospital-based study, conducted in the dental outpatient department of Nepalgunj Medical College from October 2019 to September 2020. Forty-nine patients who were diagnosed histopathologically with oral submucous fibrosis were included. The patients were divided into two groups. In group A, patients were given, $200 \mathrm{mg}$ thrice daily for first 30 days, then dose hiked to $400 \mathrm{mg}$ thrice daily for two more months. Group B patients received treatment with multi-vitamin capsules (B-complex one capsule before sleep daily) for three months. All patients were followed up for six months and were assessed for maximum inter-incisor opening, pain on opening of mouth and burning sensation. Results: There was no statistical difference in mouth opening at baseline and first follow up. The mouth opening was significantly more in group $A$ compared to group $B$ from second follow up which persisted till third follow up $(p<0.05)$. Pain and burning sensation significantly reduced in group $A$ compared to group $B$ from $2^{\text {nd }}$ follow up which persisted till 3rd follow up $(p<0.05)$. Few patients had nausea, dyspepsia and vomiting during treatment in group A which resolved within a few days without the need for cessation of the drug. Conclusion: Pentoxifylline can bring about significant clinical improvements in the symptoms of oral submucous fibrosis like mouth opening, pain and burning sensation, thereby improving the quality of life of the affected individuals.
\end{abstract}

Keywords: Oral submucous fibrosis, Pentoxifylline

Authors:

1. Dwarika Prasad Bajgai

2. Bela Agrawal

3. Abadhesh Yadav

${ }^{1}$ Department of Dental, Nepalgunj Medical College and Teaching Hospital, Nepalgunj, Banke

${ }^{2}$ Department of Oral and Maxillofacial Surgery, Bangabandhu Sheikh Mujib Medical University, Dhaka, Bangladesh

\section{Address for Correspondence:}

Dwarika Prasad Bajgai

Department of Dental

Nepalgunj Medical College and Teaching Hospital

Nepalgunj, Banke

Email: drdwarika@yahoo.com

\section{INTRODUCTION}

Oral submucous fibrosis (OSF) is a potentially malignant disease characterized by gradual inability to open the mouth. ${ }^{1}$ It is due to oral submucosal juxta-epithelial inflammatory changes, accompanied by fibro elastic changes throughout the lamina propria and epithelial atrophy, resulting in oral mucosa stiffness, trismus and feeding difficulties. ${ }^{2}$ This condition is multifactorial and associated with areca nut chewing present in betel quid and gutkha. ${ }^{1}$ The components of the areca nut produce reactive oxygen species, that makes mucosa atrophic due to poor wound healing. Iron and multivitamin supplements with lycopene, stabilize and deactivate the free radicals, are the treatment choice. ${ }^{3}$ For severe cases, intralesional steroid injection, laser ablation and surgery, including fibrotomy of jaw muscles and temporomandibular joint, have been used. ${ }^{4}$ Pentoxifylline is a methyl xanthine that increases the vascularity of the mucosal layer by increasing red cell deformability, leukocyte chemotaxis, antithrombin and antiplasmin activities, and fibrinolytic activity. ${ }^{5}$ It inhibits neutrophil adhesion and activation, induces neutrophil degranulation, increases natural killer cell activity, and inhibits T-cell and B-cell activation. ${ }^{6}$

Rajendran et al used pentoxifylline in the treatment of OSMF for 7 months and reported significant improvement in subjective symptoms, of intolerance to spices and burning sensation of the mouth in $6-12$ months of follow-up in experimental group $(\mathrm{P}<0.01){ }^{7}$ However, Fedorowicz et al reviewed the trial and stated that since the patients also received local heat therapy and underwent forceful mouth stretching exercises, it was not clear if the improvement was due to the drug or to associated heat therapy and stretching exercises. ${ }^{8}$

\section{METHODS}

This was a hospital-based study conducted in the dental outpatient department of Nepalgunj Medical College from October 2019 to September 2020. Ethical approval was obtained from the Institutional Review Committee (IRC) of the Nepalgunj Medical College, Nepal. All the patients who 
were histopathologically diagnosed of oral and submucous fibrosis, above 18 years of age, who have not undergone any previous treatments for OSF and ready for regular follow ups were included in the study. Outcome variables are maximum inter-incisal opening (MIO), pain in opening mouth (measured by visual analog scale), burning sensation on chewing, and adverse effect of drugs. MIO was measured as the distance between the center of incisal edges of maxillary central incisors and mandibular central incisor in dentates and the inter ridge (alveolar) distance along the midline in edentulous, at maximum opened mouth when patient is at comfortable and pain free position. For pain assessment by visual analog scale of score 1-10, the score of 0-1 was considered as absent, 1-6 was reduced and 7-10 present.

The patients were divided into two groups (Group A - case and Group B - control). Group A patients received treatment with initial a dosage of pentoxifylline (i.e., $200 \mathrm{mg}$ thrice daily) first 30 days. After 4 weeks liver function test (LFT), serum electrolytes, coagulation profile and serum creatinine were done to record the adverse effect of pentoxifylline. The dose then hiked to $400 \mathrm{mg}$ thrice daily for 2 more months. Group B patients received treatment with multi-vitamin capsules (B-complex one capsule before sleep daily) for 3 months. First follow up was after 21 days of initiation of treatment, second follow was at 3 months and the last at the end of 6 months. During followup patients were assessed for maximum $\mathrm{MIO}$, pain on opening of mouth and burning sensation. The data collected from the patients were analyzed using SPSS (statistical package for the social science) version 25 statistical software. The findings of the study were presented by frequency, percentage in tables. Means and standard deviations for continuous variables and frequency distributions for categorical variables were used to describe. Associations of categorical data were assessed using Chi-squared test and Fisher Exact test while associations of continuous data were assessed using Student's t test where $p<0.05$ was considered significant. Here, all $p$-values were two sided.

\section{RESULTS}

\begin{tabular}{|c|c|c|c|c|}
\hline Particulars & $\begin{array}{c}\text { Group A } \\
(n=25)\end{array}$ & $\begin{array}{c}\text { Group B } \\
(n=24)\end{array}$ & $\begin{array}{l}\text { Total } \\
(n=49)\end{array}$ & $P$ value \\
\hline \multicolumn{5}{|l|}{ Age (in years) } \\
\hline $30-39$ & $\begin{array}{c}10 \\
(40 \%)\end{array}$ & $\begin{array}{c}9 \\
(37.5 \%)\end{array}$ & & \multirow{5}{*}{0.559} \\
\hline $40-49$ & $\begin{array}{c}5 \\
(20.0 \%)\end{array}$ & $\begin{array}{c}7 \\
(29.2 \%)\end{array}$ & & \\
\hline $50-59$ & $\begin{array}{c}5 \\
(20.0 \%)\end{array}$ & $\begin{array}{c}7 \\
(29.2 \%)\end{array}$ & & \\
\hline $60-69$ & $\begin{array}{c}5 \\
(20.0 \%)\end{array}$ & $\begin{array}{c}1 \\
(4.2 \%)\end{array}$ & & \\
\hline Mean \pm SD & $46.27 \pm 11.57$ & $44 \pm 8.99$ & & \\
\hline \multicolumn{5}{|l|}{ Gender } \\
\hline Male & $\begin{array}{c}4 \\
(16.0 \%)\end{array}$ & $\begin{array}{c}6 \\
(25.0 \%)\end{array}$ & $\begin{array}{c}10 \\
(20.5 \%)\end{array}$ & 0.496 \\
\hline Female & $\begin{array}{c}21 \\
(84.0 \%)\end{array}$ & $\begin{array}{c}18 \\
(75.0 \%)\end{array}$ & $\begin{array}{c}39 \\
(79.6 \%)\end{array}$ & \\
\hline \multicolumn{5}{|c|}{ Educational Status } \\
\hline
\end{tabular}

\begin{tabular}{|c|c|c|c|c|}
\hline $\begin{array}{l}\text { No Formal } \\
\text { education }\end{array}$ & $\begin{array}{c}5 \\
(20.0 \%)\end{array}$ & $\begin{array}{c}7 \\
(29.2 \%)\end{array}$ & $\begin{array}{c}12 \\
(24.5 \%)\end{array}$ & \multirow[t]{2}{*}{0.520} \\
\hline Literate & $\begin{array}{c}20 \\
(80.0 \%)\end{array}$ & $\begin{array}{c}17 \\
(70.08 \%)\end{array}$ & $\begin{array}{c}37 \\
(75.5 \%)\end{array}$ & \\
\hline \multicolumn{5}{|c|}{ Socioeconomic status } \\
\hline Poor & $\begin{array}{c}14 \\
(56.0 \%)\end{array}$ & $\begin{array}{c}14 \\
(58.3 \%)\end{array}$ & $\begin{array}{c}28 \\
(57.1 \%)\end{array}$ & \multirow{3}{*}{1.000} \\
\hline Middle class & $\begin{array}{c}8 \\
(32.0 \%)\end{array}$ & $\begin{array}{c}7 \\
(29.2 \%)\end{array}$ & $\begin{array}{c}15 \\
(30.6 \%)\end{array}$ & \\
\hline Rich & $\begin{array}{c}3 \\
(12.0 \%)\end{array}$ & $\begin{array}{c}3 \\
(12.0 \%)\end{array}$ & $\begin{array}{c}6 \\
(12.2 \%)\end{array}$ & \\
\hline
\end{tabular}

Table I: Demographical Data of Patients

\begin{tabular}{|c|c|c|c|c|}
\hline & $\begin{array}{c}\text { Group A } \\
(n=25)\end{array}$ & $\begin{array}{c}\text { Group B } \\
(n=24)\end{array}$ & $\begin{array}{c}\text { Total } \\
(n=49)\end{array}$ & $\begin{array}{c}P \\
\text { value }\end{array}$ \\
\hline \multicolumn{5}{|l|}{ Site } \\
\hline Right & $\begin{array}{c}9 \\
(36.0 \%)\end{array}$ & $\begin{array}{c}8 \\
(33.3 \%)\end{array}$ & $\begin{array}{c}17 \\
(34.7 \%)\end{array}$ & \multirow{3}{*}{0.563} \\
\hline Left & $\begin{array}{c}3 \\
(12.0 \%)\end{array}$ & $\begin{array}{c}6 \\
(25.0 \%)\end{array}$ & $\begin{array}{c}9 \\
(18.4 \%)\end{array}$ & \\
\hline Both & $\begin{array}{c}13 \\
(52.0 \%)\end{array}$ & $\begin{array}{c}10 \\
(41.7 \%)\end{array}$ & $\begin{array}{c}23 \\
(46.9 \%)\end{array}$ & \\
\hline \multicolumn{5}{|c|}{ Betel quid and gutkha chewing habit } \\
\hline No & $\begin{array}{c}1 \\
(4.0 \%)\end{array}$ & $\begin{array}{c}1 \\
(4.2 \%)\end{array}$ & $\begin{array}{c}2 \\
(4.1 \%)\end{array}$ & \multirow[t]{2}{*}{1.000} \\
\hline yes & $\begin{array}{c}24 \\
(96.0 \%)\end{array}$ & $\begin{array}{c}24 \\
(95.8 \%)\end{array}$ & $\begin{array}{c}47 \\
(95.9 \%)\end{array}$ & \\
\hline
\end{tabular}

Table II: Comparison between site of OSF and betel quid and gutkha chewing habit between two groups

\begin{tabular}{|llll}
\hline $\begin{array}{c}\text { Mouth opening } \\
\text { (in } \mathbf{~ m m})\end{array}$ & $\begin{array}{c}\text { Group A } \\
(\mathbf{n}=\mathbf{2 5})\end{array}$ & $\begin{array}{c}\text { Group B } \\
(\mathbf{n}=\mathbf{2 4})\end{array}$ & p-value \\
\hline Baseline & $25.88 \pm 3.42$ & $25.79 \pm 3.46$ & 0.929 \\
\hline $1^{\text {st }}$ follow up & $26.52 \pm 3.20$ & $26.29 \pm 3.19$ & 0.804 \\
\hline $2^{\text {nd }}$ follow up & $28.80 \pm 2.81$ & $27.17 \pm 2.55$ & 0.039 \\
\hline $3^{\text {rd }}$ follow up & $30.00 \pm 3.00$ & $27.71 \pm 2.14$ & 0.004 \\
\hline
\end{tabular}

Table III: Comparison of mouth opening between two groups

\begin{tabular}{|lccc|}
\hline Pain status & $\begin{array}{c}\text { Group A } \\
(\mathbf{n = 2 5})\end{array}$ & $\begin{array}{c}\text { Group B } \\
(\mathbf{n = 2 4 )}\end{array}$ & p-value \\
\hline Baseline & 12 & 9 & \\
\hline Absent & $(48.0 \%)$ & $(37.5 \%)$ & 0.567 \\
\hline Present & 13 & 15 & \\
\hline $\mathbf{1}^{\text {st }}$ follow up & $(52.0 \%)$ & $(62.5 \%)$ & \\
\hline Absent & 16 & & \\
\hline Present & $(64.0 \%)$ & $(50.0 \%)$ & 0.394 \\
\hline Reduced & 4 & 8 & \\
2 & $(16.0 \%)$ & $(33.3 \%)$ & 4 \\
follow up & $(20.0 \%)$ & $(16.7 \%)$ & \\
\hline Absent & 19 & 15 & \\
\hline
\end{tabular}




$\begin{array}{lccc}\text { Present } & 1 & 7 & 0.036 \\ \text { Reduced } & (4.0 \%) & (29.2 \%) & \\ 3^{\text {rd }} \text { follow up } & 5 & 2 & \\ \text { Absent } & (20.0 \%) & (8.3 \%) & \\ & (96.0 \%) & (70.8 \%) & 0.037 \\ \text { Present } & 0 & 2 & \\ \text { Reduced } & (0.0 \%) & (8.3 \%) & \\ & 1 & 5 & \\ & (4.0 \%) & (20.8 \%) & \end{array}$

Table IV: Comparison of pain status between two groups

\begin{tabular}{|c|c|c|c|}
\hline Burning sensation & $\begin{array}{c}\text { Group A } \\
(n=25)\end{array}$ & $\begin{array}{c}\text { Group B } \\
(n=24)\end{array}$ & p-value \\
\hline \multicolumn{4}{|l|}{ Baseline } \\
\hline Absent & $\begin{array}{c}12 \\
(48.0 \%)\end{array}$ & $\begin{array}{c}8 \\
(33.3 \%)\end{array}$ & 0.296 \\
\hline Present & $\begin{array}{c}13 \\
(52.0 \%)\end{array}$ & $\begin{array}{c}16 \\
(66.7 \%)\end{array}$ & \\
\hline \multicolumn{4}{|l|}{$1^{\text {st }}$ follow up } \\
\hline Absent & $\begin{array}{c}19 \\
(76.0 \%)\end{array}$ & $\begin{array}{c}12 \\
(50.0 \%)\end{array}$ & \\
\hline Present & $\begin{array}{c}2 \\
(8.0 \%)\end{array}$ & $\begin{array}{c}8 \\
(33.3 \%)\end{array}$ & 0.086 \\
\hline Reduced & $\begin{array}{c}4 \\
(16.0 \%)\end{array}$ & $\begin{array}{c}4 \\
(16.7 \%)\end{array}$ & \\
\hline \multicolumn{4}{|l|}{$2^{\text {nd }}$ follow up } \\
\hline Absent & $\begin{array}{c}19 \\
(76.0 \%)\end{array}$ & $\begin{array}{c}15 \\
(62.5 \%)\end{array}$ & \\
\hline Present & $\begin{array}{c}1 \\
(4.0 \%)\end{array}$ & $\begin{array}{c}7 \\
(29.2 \%)\end{array}$ & 0.036 \\
\hline Reduced & $\begin{array}{c}5 \\
(20.0 \%)\end{array}$ & $\begin{array}{c}2 \\
(8.3 \%)\end{array}$ & \\
\hline \multicolumn{4}{|l|}{$3^{\text {rd }}$ follow up } \\
\hline Absent & $\begin{array}{c}25 \\
(100.0 \%)\end{array}$ & $\begin{array}{c}18 \\
(75.0 \%)\end{array}$ & 0.010 \\
\hline Reduced & $\begin{array}{c}0 \\
(0.0 \%)\end{array}$ & $\begin{array}{c}6 \\
(25.0 \%)\end{array}$ & \\
\hline
\end{tabular}

Table V: Comparison of burning sensation between two groups

\section{Adverse effect on group A during treatment}

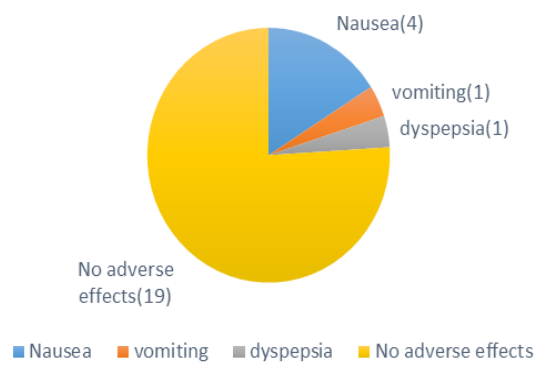

Figure 1: Adverse effect on group A during treatment $(n=25)$
Forty-nine cases were enrolled in this study, 25 in group A and 24 in Group B. Table I shows that here was no statistically significant difference in relation to age, gender, educational status and socioeconomic status. Also, there was not any significant statistical difference between two groups in relation to sites of OSF, and betel quid and gutkha chewing habits as shown in Table II.

There was no statistical difference in mouth opening at $1^{\text {st }}$ follow up (Table III). Statistically significant difference was found between two groups at $2^{\text {nd }}$ and $3^{\text {rd }}$ follow up $(p=<0.05)$. Table IV shows that there was no statistical difference in pain status at the $1^{\text {st }}$ follow up. Statistically significant difference between two groups at $2^{\text {nd }}$ and $3^{\text {rd }}$ follow up regarding pain status $(p=<0.05)$.

Similarly, as shown in table $V$ there was no statistical difference in burning sensation at baseline and at $1^{\text {st }}$ follow up. However, when compared at $2^{\text {nd }}$ and $3^{\text {rd }}$ follow up it was significant $(p=$ $<0.05)$.

During treatment $4(16.0 \%)$ patients had nausea, $1(4.0 \%)$ had dyspepsia and 1(4.0\%) had vomiting as shown in Figure 1.

\section{DISCUSSION}

Oral submucous fibrosis is a premalignant disease of the oral cavity characterized by inflammation and progressive fibrosis of the submucosal tissues, resulting in pronounced rigidity and trismus. The treatment of OSF depends on the degree of disease progression and clinical involvement. At early stages, stopping habit and nutritional supplements are done. At moderate stages, conservative treatment along with medical treatment is provided. At advanced stages, surgical interventions are needed. ${ }^{9}$ Oral submucous fibrosis occurs at any age but most commonly seen in young and adults between 25 and 35 years. Onset of this disease is insidious and is often 2-5 years of duration. ${ }^{10}$ The mean age of the patients in each group was more than 45 years where more than one third of the patients in both groups were from 30-39 years age group. Other studies conducting among patients with OSF found that the mean age of patients was near 35 years. ${ }^{11,12}$ This dissimilarity of result might be due the fact that the present study was conducted in a tertiary level hospital where patients came from all over the country. Most of the patients were referred from other health institutions for better treatment. This might be the reason of the delayed presentation of disease.

In both groups, majority of the participants were female. The prevalence of OSF was found to be a bit higher in female compared to male. ${ }^{13}$ Near about half of the patients had OSF on both side of buccal mucosa and one third of the participants had OSF in right side. No patient had OSF on tongue, soft palate or perygo-mandibular raphe. This might be due to the small sample size of the study.

Betel-quid and gutkha chewing are common causes of OSF. ${ }^{14}$ In both groups, most of the participants had Betel-quid and gutkha chewing habit which was consistent with other studies. ${ }^{15}$ In the present study, fibrous band was present in all patients and all 
of them had restricted mouth opening at the presentation. The mouth opening was found significantly increased in group $A$ compared to group B at three-month and six-month follow up visit. These findings correlated with the findings of Bhambal et al and Patil et al. ${ }^{12,16}$ At the beginning of the study, majority of the patients had complained of pain on opening of mouth. At the end of three-month, majority of the patients in group A did not have any pain and in one fifth patients' pain was reduced which significantly differ from group B where $29.2 \%$ patients had pain. At the end of six month, most of the patients in group $A$ had no complain of pain while in group $B$, near about one third of the patients had pain. It indicated that pentoxifylline significantly reduced pain compared to conventional treatment which was consistent with the studies of Bhambal et al and Patil et al. ${ }^{12,16}$ At six months follow up, the burning sensation was also found to be significantly reduced in group A compared to group B. Similar observation was presented by otherstudies. ${ }^{12}$, ${ }^{17}$ During treatment ingroup A, 4 patients had nausea, one had dyspepsia and one had vomiting. The symptoms were mild in nature and resolved within a few days, without the need for cessation of the drug. This was similar to the findings of Mehrotraet et al and Patiet al. ${ }^{4,12}$

\section{LIMITATIONS}

Small sample size and short follow up time is the limitation of study. The results of this study need to be confirmed in a larger population of OSF patients with a longer period of follow-up. In addition, further study is needed to evaluate the effectiveness of pentoxifylline on the basis of extent of efficacy in different age groups, at various grades of OSMF, and duration of habit associated with OSMF.

\section{CONCLUSION}

The results of the present study showed that pentoxifylline can bring about significant clinical improvements in the symptoms of OSF like mouth opening, pain and burning sensation, thereby improving the quality of life of the affected individuals.

\section{REFERENCES}

1. Cox SC, Walker DM. Oral submucous fibrosis. A review. Australian dental journal. 1996; 41(5):294-9.

2. Pindborg JJ, Sirsat SM. Oral submucous fibrosis. Oral Surgery, Oral Medicine, Oral Pathology. 1966; 22(6):764-79.

3. Chole RH, Gondivkar SM, Gadbail AR, Balsaraf S, Chaudhary S, Dhore SV, Ghonmode S, Balwani S, Mankar M, Tiwari M, Parikh RV. Review of drug treatment of oral submucous fibrosis. Oral oncology. 2012; 48(5):393-8.

4. Mehrotra R, Singh HP, Gupta SC, Singh M, Jain S. Pentoxifylline therapy in the management of oral submucous fibrosis. Asian Pac J Cancer Prev. 2011; 12(4):971-4.

5. Ward A. Clissold, SP. Pentoxifylline. A review of its pharmacodynamic and pharmacokinetic properties, and its therapeutic efficacy. Drugs. 1987; 34:50-97.
6. Cavalcanti AL, Reis MY, Silva GC, Ramalho ÍM, Guimarães GP, Silva JA, Saraiva KL, Damasceno BP. Microemulsion for topical application of pentoxifylline: in vitro release and in vivo evaluation. International journal of pharmaceutics. 2016; 506(1-2):351-60.

7. Rajendran R, Deepthi K, Nooh N, Anil S. $\alpha 4 \beta 1$ integrindependent cell sorting dictates T-cell recruitment in oral submucous fibrosis. Journal of oral and maxillofacial pathology: JOMFP. 2011; 15(3):272.

8. Fedorowicz Z, Shih-Yen EC, Dorri M, Nasser M, Newton T, Shi L. Interventions for the management of oral submucous fibrosis. Cochrane Database of Systematic Reviews. 2008(4).

9. Passi D, Bhanot P, Kacker D, Chahal D, Atri M, Panwar Y. Oral submucous fibrosis: Newer proposed classification with critical updates in pathogenesis and management strategies. National journal of maxillofacial surgery. 2017 Jul;8(2):89.

10. Sabarinath B, Sriram G, Saraswathi TR, Sivapathasundharam B. Immunohistochemical evaluation of mast cells and vascular endothelial proliferation in oral submucous fibrosis. Indian Journal of Dental Research. 2011 Jan 1;22(1):116.

11. Mehrotra R, Singh HP, Gupta SC, Singh M, Jain S. Pentoxifylline therapy in the management of oral submucous fibrosis. Asian Pac J Cancer Prev. 2011 Jan 1; 12(4):971-4.

12. Patil S, Maheshwari S. Efficacy of pentoxifylline in the management of oral submucous fibrosis. Journal of Orofacial Sciences. 2014; 6(2):94.

13. More $C B$, Rao NR. Proposed clinical definition for oral submucous fibrosis. Journal of oral biology and craniofacial research. 2019; 9(4):311-4.

14. Tilakaratne WM, Klinikowski MF, Saku T, Peters TJ, Warnakulasuriya S. Oral submucous fibrosis: review on aetiology and pathogenesis. Oral oncology. 2006; 42(6):5618.

15. Patil S, Maheshwari S. Efficacy of pentoxifylline in the management of oral submucous fibrosis. Journal of Orofacial Sciences. 2014;6(2):94.

16. Bhambal AM, Bhambal A, Shukla US, Dhingra A. Effectiveness of Pentoxifylline in the treatment of oral submucous fibrosis patients: a case-control study. Applied Cancer Research. 2019; 39(1):1-9.

17. Kalkur C, Sattur AP, Guttal KS, Lakshman AR. "Introducing modified Dakkak and Bennett grading system for Indian food in Oral submucous fibrosis": a Dharwad study. Journal of dietary supplements. 2019; 16(2):207-14. 